تأثير لجن فاضلاب بر رشد و برخى عناصر غذايى سه زنوتيب كينوا در يك خاك آهكى و شور فاطمه افضلى نزاد'، سميه قاسمى ا"*، سيدابراهيم سيفتى و شيما شهبازى منشادى'

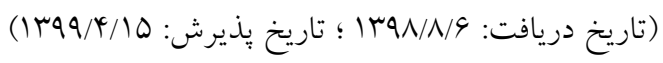

جكيده

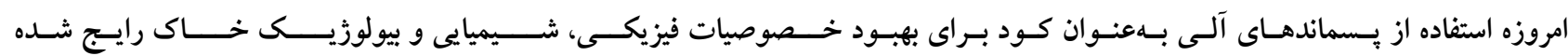

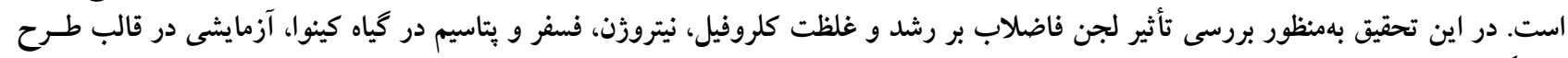

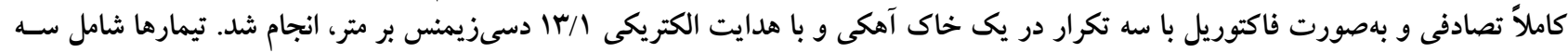

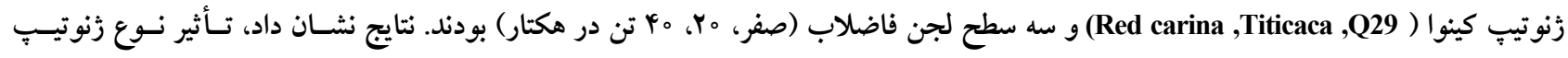

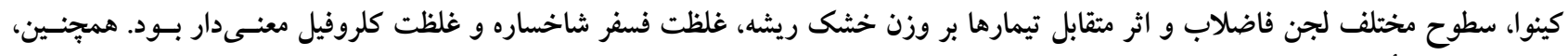

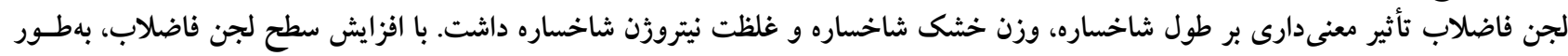

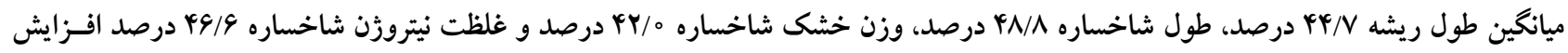

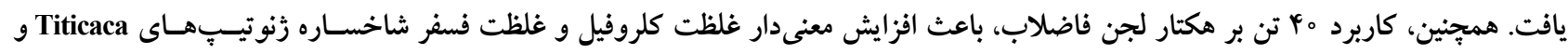

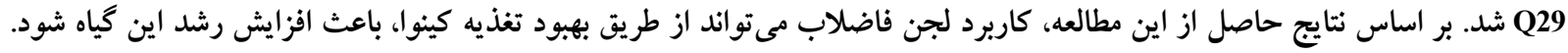

وازههاى كليدى: لجن فاضلاب، Q29، Titicaca ،Red carina، عناصر يرمصرف

( ا. كروه علوم خاك، دانشكده منابع طبيعى، دانشكاه يزد، يزد

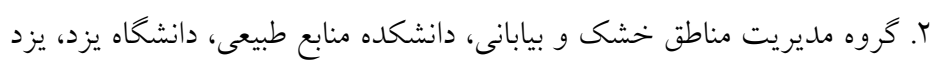

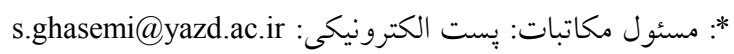


بسماندهاى آلى اسـت كـهـ از طريق بهبود خصوصيات فيزيكى

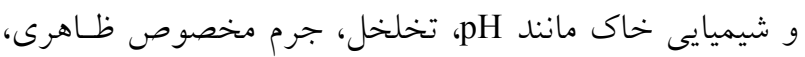

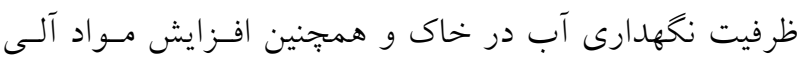

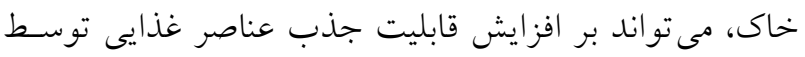

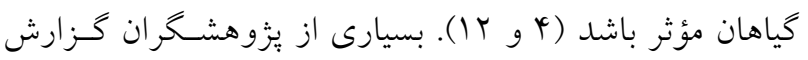
كردهاند كه با افزودن لجن فاضلاب به خاك، pH خاك بهدليل

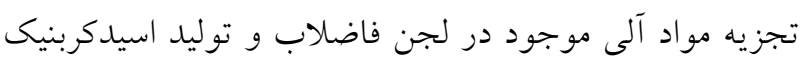

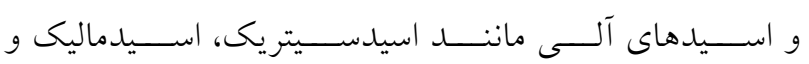
اسيديروييونيك كـاهش مسى يابـد. نتيجـه كـاهش pH خـاك، افزايش حلاليت و قابليت دسترسى برخى از عناصسر در خـاك

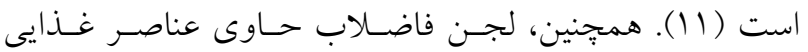

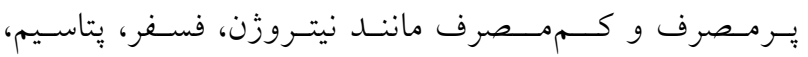

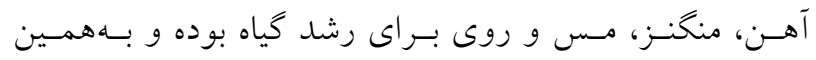

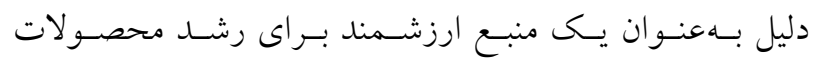

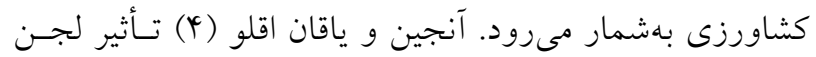

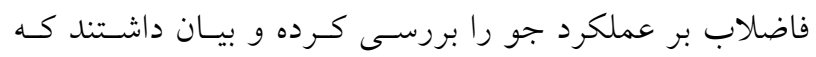

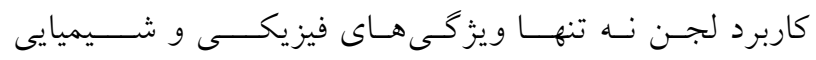

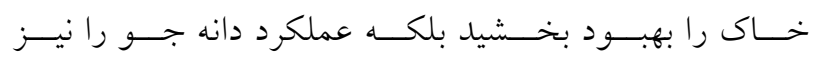

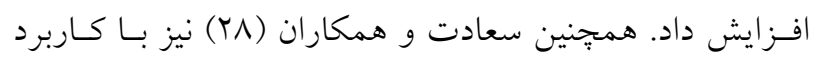

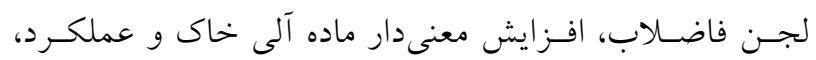

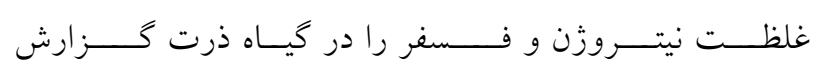

در ايران، لجن فاضلاب بيشتر بهدليـل ارزانسى قيمـت ايسن

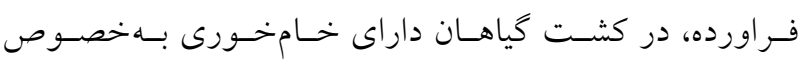

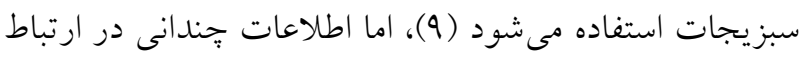

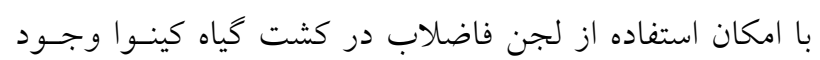

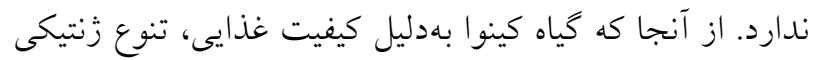
و سازكارى وسيع به شرايط خاك و اقليمهاى مختلف و و هزينه كم توليد، مى تو اند در كشورهاى مختلف به كيـاه اسـتراتزيك

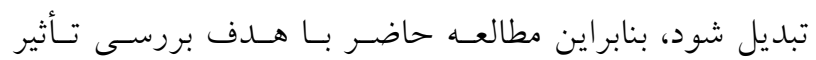

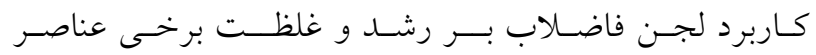
يرمصرف در سه زُنوتيب گياه كينوا انجام شد.

از نظر اقليمى بخش عمده مساحت ايران جزء مناطق خشك

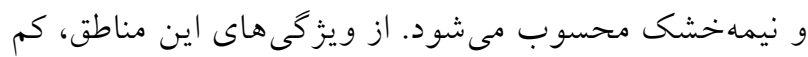

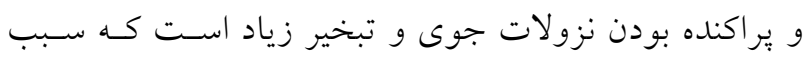
تجمع املاح در لايههاى سطحى خاك مى شود. بههمين دليل،

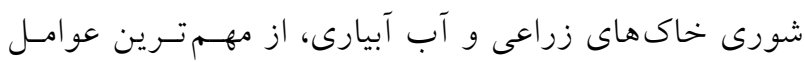

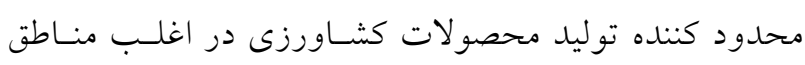

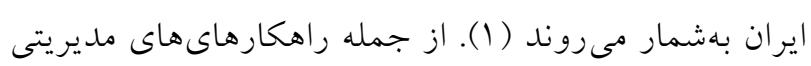

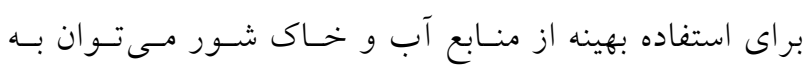

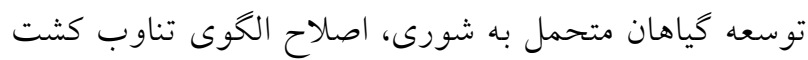

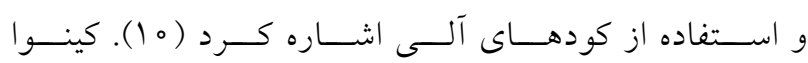
يكى از كياهـان زراعى (Chenopodium quinoa, Willd) است كه مقاومت زيادى در برابر طيف وسيعى از تسنشهـاى

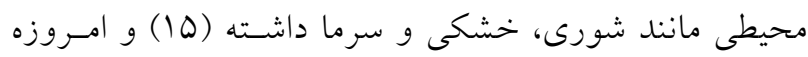

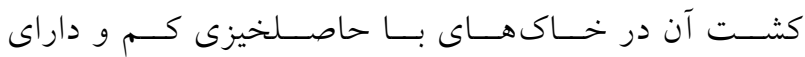

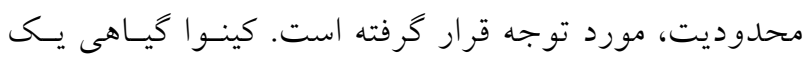

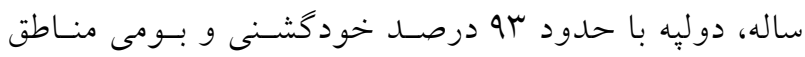

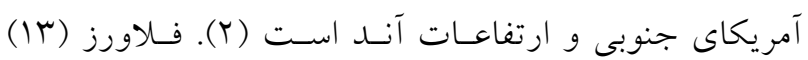

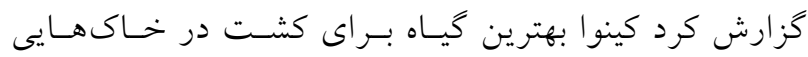

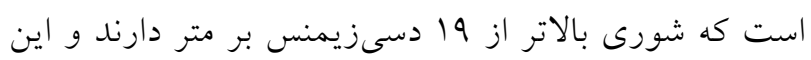

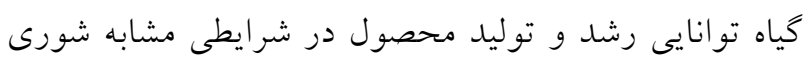

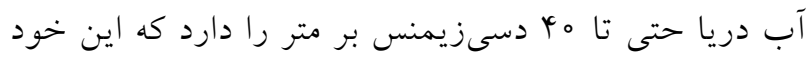

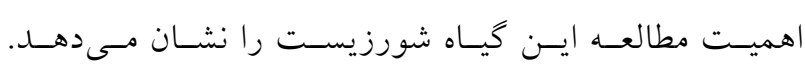

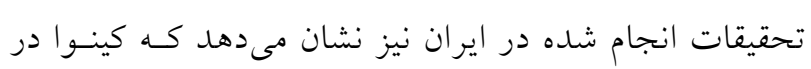
برخى مناطق ايران قابل كشت بوده (V) و در آينـده جايخـاه

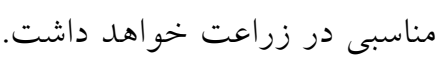

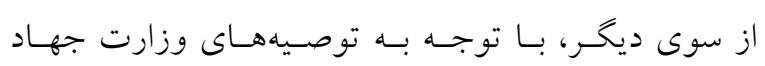

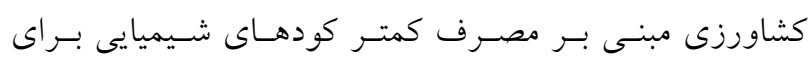

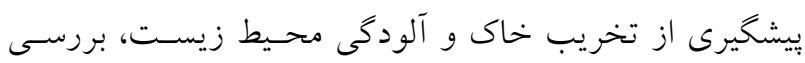

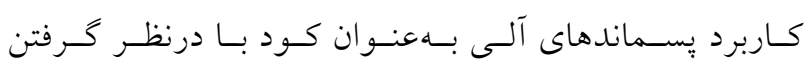

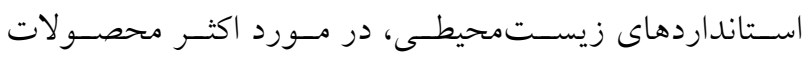

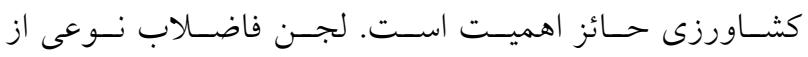


جدول ا. برخى ويزگى هاى لجن فاضلاب مورد آزمايش

\begin{tabular}{|c|c|c|c|}
\hline حد استاندارد لجن فاضلاب (T9) & مقدار & واحد & 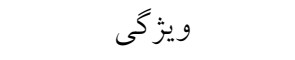 \\
\hline- & $9 / 0 r$ & - & $\mathrm{pH}$ \\
\hline- & $9 / 94$ & $\mathrm{dS} \mathrm{m}^{-1}$ & قابليت هدايت الكتريكى \\
\hline كمتر از هoه & $r r / 。$ & $\mathrm{MPN} / \mathrm{g}$ & كليفرم كو ارشى \\
\hline- & $\kappa V / 0$ & $(\%)$ & ماده آلى \\
\hline- & $r / \circ r$ & $(\%)$ & نيتروزن كل \\
\hline- &.$/ 01$ & $(\%)$ & يتاسيم كل \\
\hline- & $r / 19$ & $(\%)$ & فسفر كل \\
\hline rq & $0 / 41$ & $\mathrm{mg} \mathrm{kg}^{-1}$ & كادميوم \\
\hline ro。 & $r / r)$ & $\mathrm{mg} \mathrm{kg}^{-1}$ & سرب \\
\hline kro & $\Delta / r Q$ & $\mathrm{mg} \mathrm{kg}^{-1}$ & نيكل \\
\hline 1000 & krv & $\mathrm{mg} \mathrm{kg}^{-1}$ & 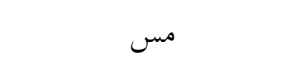 \\
\hline rAo。 & $91 r$ & $\mathrm{mg} \mathrm{kg}^{-1}$ & روى \\
\hline IVooo & roo & $\mathrm{mg} \mathrm{kg}^{-1}$ & آهن \\
\hline rqo & rIT & $\mathrm{mg} \mathrm{kg}^{-1}$ & منغنز \\
\hline 4 & N.D & $\mathrm{mg} \mathrm{kg}^{-1}$ & آرسنيك \\
\hline Iroo & $r / 09$ & $\mathrm{mg} \mathrm{kg}^{-1}$ & كروم \\
\hline IV & N.D & $\mathrm{mg} \mathrm{kg}^{-1}$ & جيوه \\
\hline
\end{tabular}

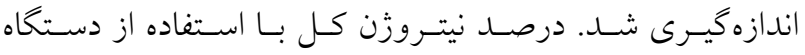

اتوكلتك مــدل Behr distilliation unit S4 بـر اســـ روش روش كلدال تعيين شد. همجنين غلظت فلزات سنخين بعد از انحـلال

در تيزاب با دستكاه جذب اتمى مدل Novaa300 تعيين شد. براى كشت كياه، ابتدا سطوح مختلف لجن فاضلاب بـا وزن مشخصى از خاك با ويزّكى هاى فيزيكى و شيميايى ذكر شده در

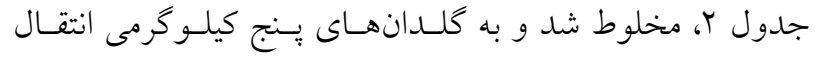

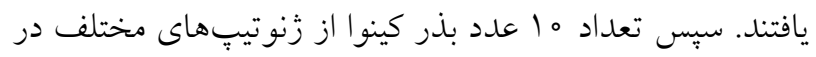

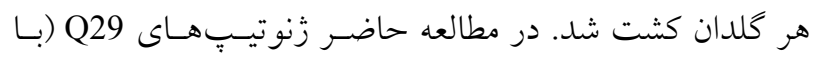

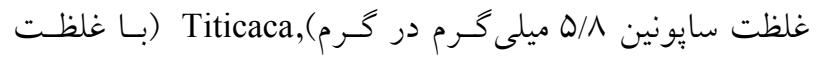

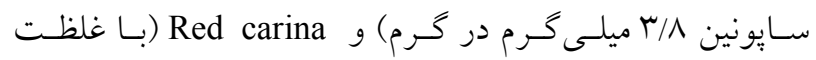

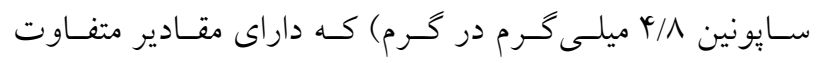

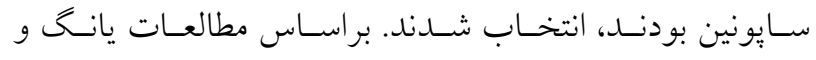

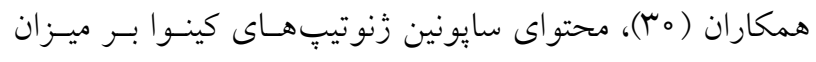

در اين بزوهش، بهمنظور بررسى تأثير كساربرد سطوح مختلـف

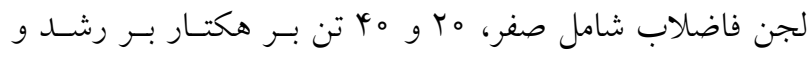

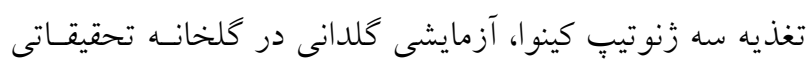

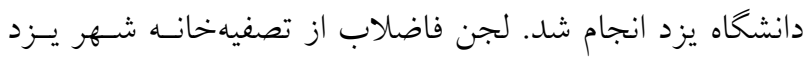

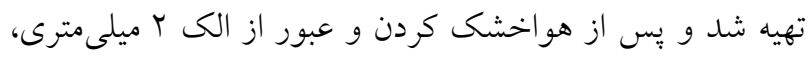

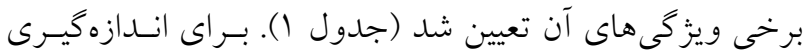
pH

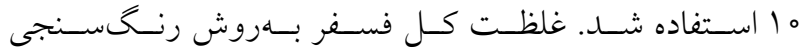
موليبدوو انادات با دستخاه اسيكتروفتومتر مـــS Specord 210 در

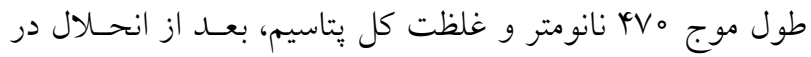

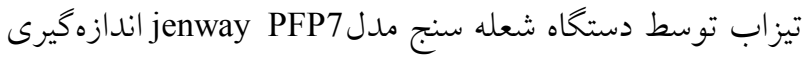

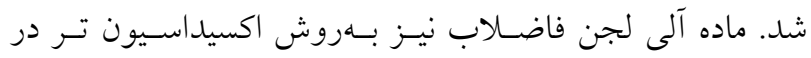

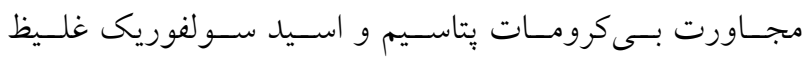


جدول r. برخى ويزگكىهاى فيزيكى و شيميايى خاك مورد مطالعه

\begin{tabular}{|c|c|c|c|c|c|c|c|c|c|c|}
\hline مس & منكنز & آهن & فسفر قابل & شيتاسيم قابل & نيتروزن & كربن & كربنات & \multirow[t]{2}{*}{$\mathrm{pH}$} & $\mathrm{EC}$ & \multirow[t]{2}{*}{ كلاس بافت } \\
\hline \multicolumn{5}{|c|}{$\mathrm{mg} \mathrm{kg}^{-1}$} & \multicolumn{3}{|c|}{$\%$} & & $\mathrm{dS} \mathrm{m}^{-1}$ & \\
\hline $1 / 90$ & $1 / \circ \Lambda$ & $r / 90$ & $Y \circ / D Q$ & $1 r_{0}$ & $0 / 04$ & $\circ / 1 \Lambda$ & ir & $N / 01$ & $1 r / \circ 9$ & لوم رسى - شنى \\
\hline
\end{tabular}

اين آزمايش بهصسورت فاكتوريـل و در قالـب طـرح كـاملاً

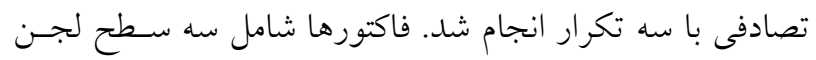

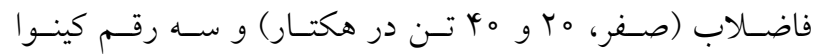
بودند. تجزيهو تحليـل دادههـا بـا (Red carina ,Titicaca ,Q29) اسـتفاده از تجزيــهـ واريــانس دو طرفــه توســط نــــرمافـزار SPPS Statistucs 20

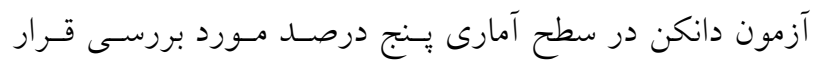
Sرفت. براى رسم نمودارها از نرمافزار 2013 Microsoft Excel

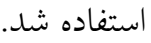

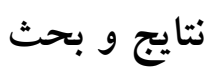

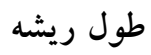

بر اساس نتايج بهدست آمده از تجزيسه واريـانس دادههـا، تـأثير

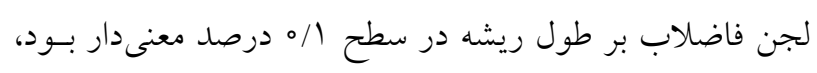

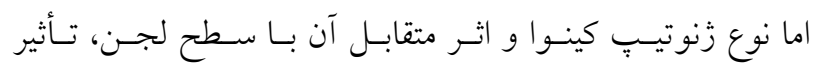

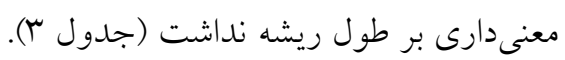

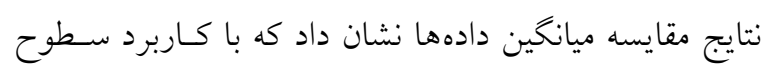

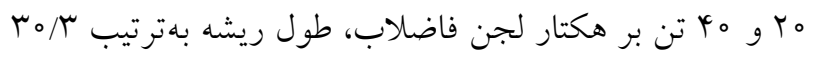

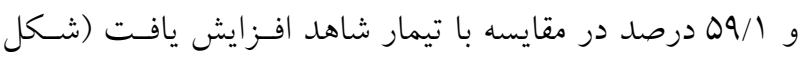

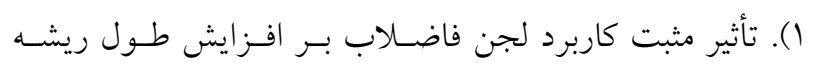

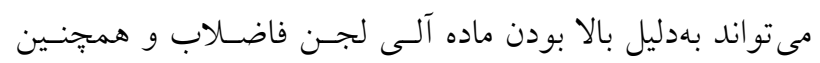

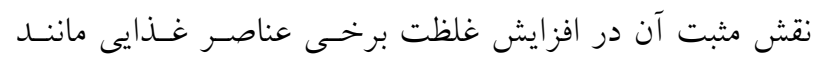

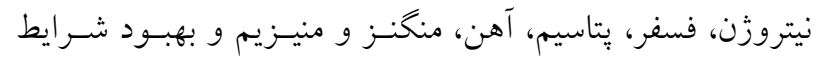

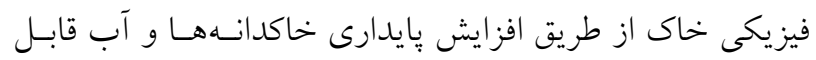

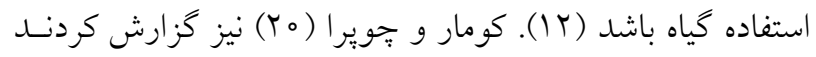
كـه كـاربرد لجـن فاضـلاب باعـث افـزايش عملكــــد بادمجــان
تحمل آنها به سطوح مختلف تنش، مؤثر است. براى هـر تيمـار

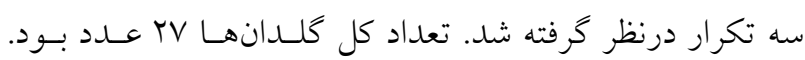

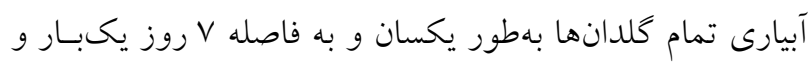

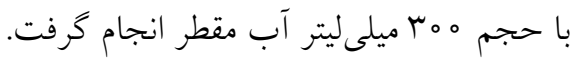

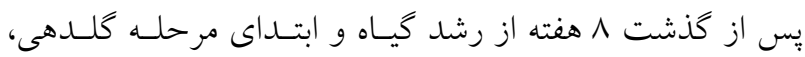

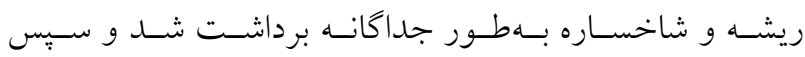
پارامترهايى از قبيل طول ريشه و شاخساره، وزن خشك ريشه و شاخساره و غلظت كلروفيل، نيتروزن، بِتاسيم و فسفر شاخسـاره اندازه كيرى شد.

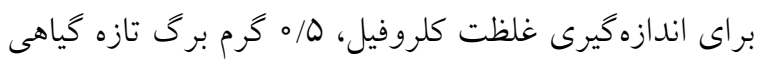

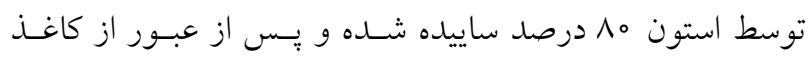

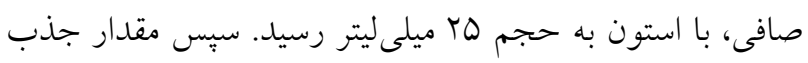

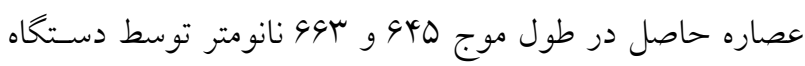
اسبكتروفتومتر قرائت شد (9).

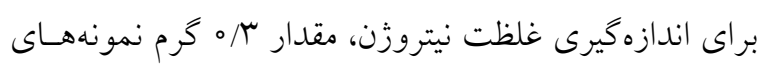

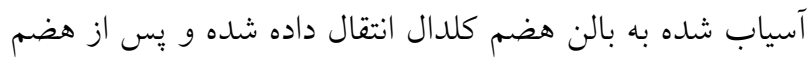

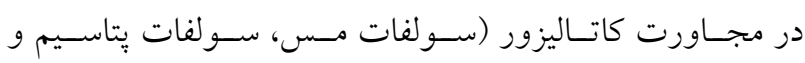

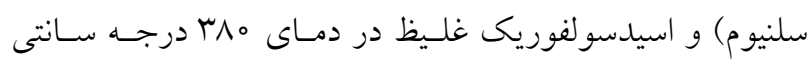
كراد بهمدت سه ساعت، غلظت نيتروزن توسط دستخاه اتو كلتك استى

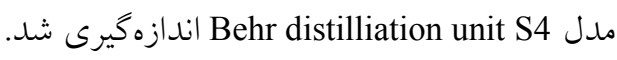

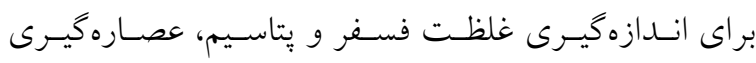

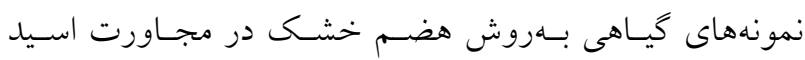

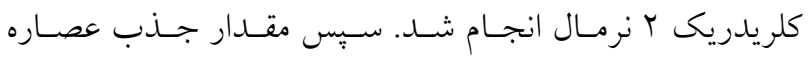

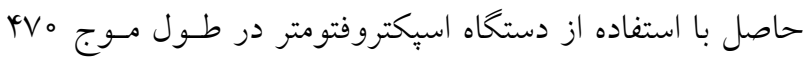
نانومتر قرائت شد. غلظت يتاسـيم شاخسـاره نيـز بــا اسـتفاده از

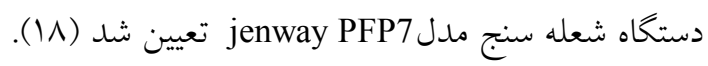


جدول r. نتايج تجزيه واريانس تأثير سطوح مختلف لجن فاضلاب بر ويزگىهاى مورفولوزيكى سه زنوتيب كينوا

\begin{tabular}{|c|c|c|c|c|c|}
\hline \multicolumn{4}{|c|}{ ميانخين مربعات } & \multirow[b]{2}{*}{ درجه آزادى } & \multirow[b]{2}{*}{ منابع تغييرات } \\
\hline وزن خشك شاخساره & وزن خشك & طول شاخساره & طول ريشه & & \\
\hline $1 / 10$ & $\circ / 11 \wedge^{* *}$ & $\mathrm{~V} / \mathrm{Al}$ & $|V /|$ & r & زَنوتيب \\
\hline$N / \Delta Y^{* * * *}$ & $\circ / \circ \wedge 9^{* *}$ & 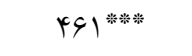 & $199^{* * *}$ & r & سطح لجن \\
\hline T/AD & $\circ / \circ \Delta Q^{*}$ & TN/T & $4 / 10$ & r & زنوتيبٍ × سطح لجن \\
\hline $1 / T r$ & $0 / 014$ & $11 / 10$ & $9 / 11$ & 11 & خطاى آزمايش \\
\hline
\end{tabular}

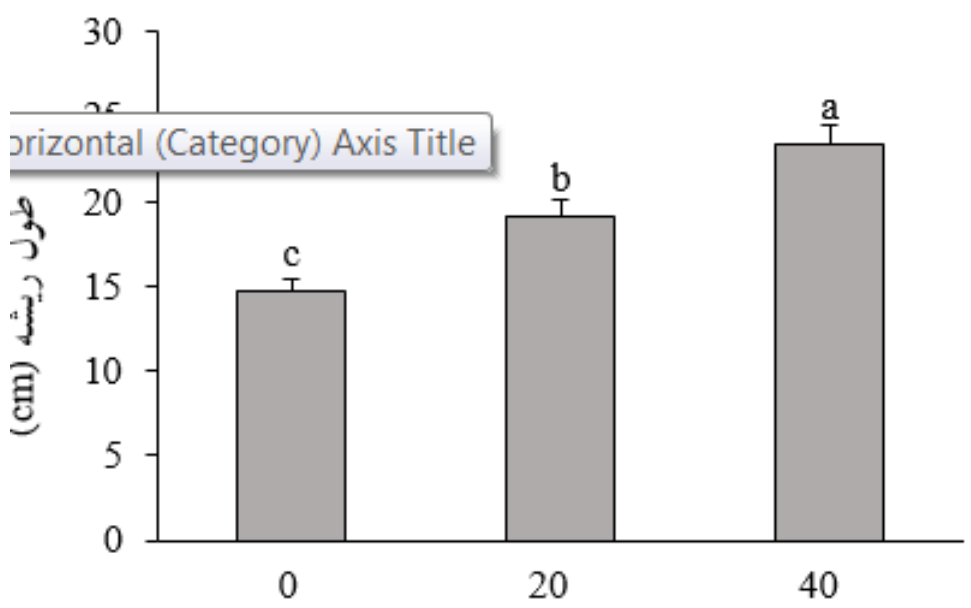

(ton ha-1) سطوح مختلف لجن فاضلانب

شكل 1. تأثير سطوح مختلف لجن فاضلاب بر طول ريشه كينوا

(ميانخينهاى با حداقل يك حرف مشترى بيانگر عدم تفاوت معنىدار در سطح ه درصد آزمون دانكن هستند.)

شد و حداكثر طول ريشه كياه مربوط به تيمار مه درصــ لجـن وضعيت حاصلخيزى خاك ناشى از افزودن لجن فاضلاب به خـاك

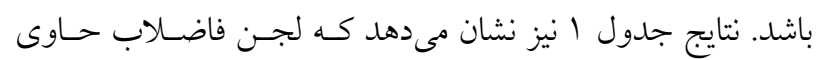

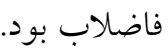

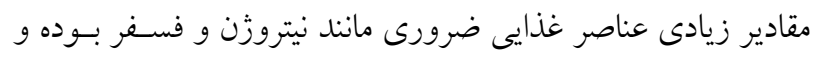

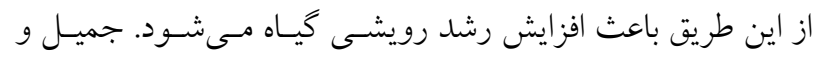

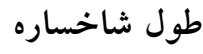

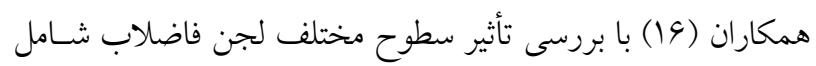

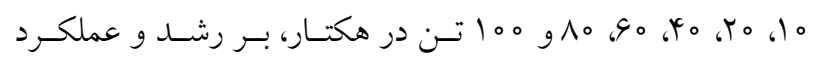

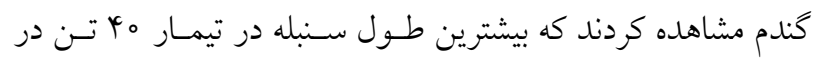

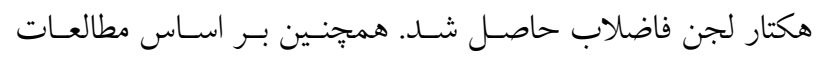

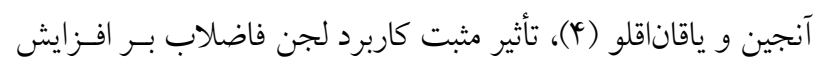

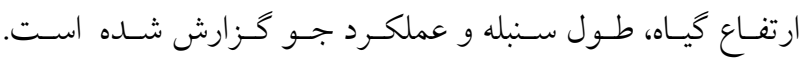
تأثير سطوح مختلف لجن فاضـلاب بـر طـول شاخسـاره كينـوا در

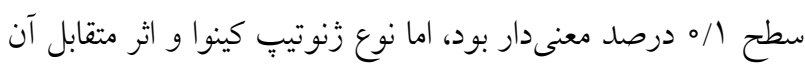
با سطح لجن فاضلاب، تأثير معنى دارى بر طول شاخسـاره نداشـتند

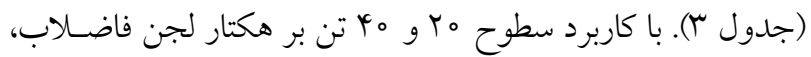

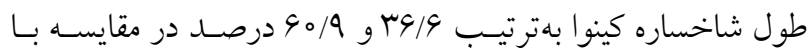

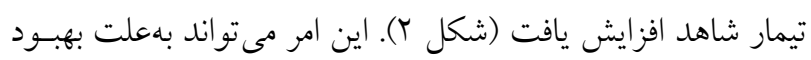




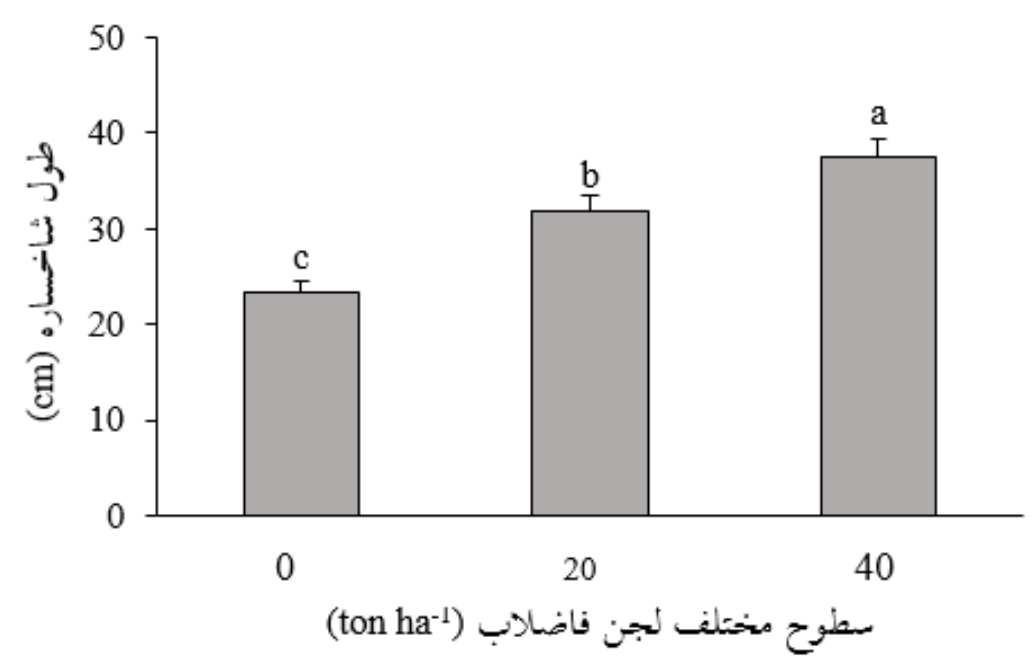

شكل r. تأثير سطوح مختلف لجن فاضلاب بر طول شاخساره كينوا

(ميانكينهاى با حداقل يك حرف مشترى، بيانكر عدم تفاوت معنىدار در سطح ه درصد آزمون دانكن هستند.)

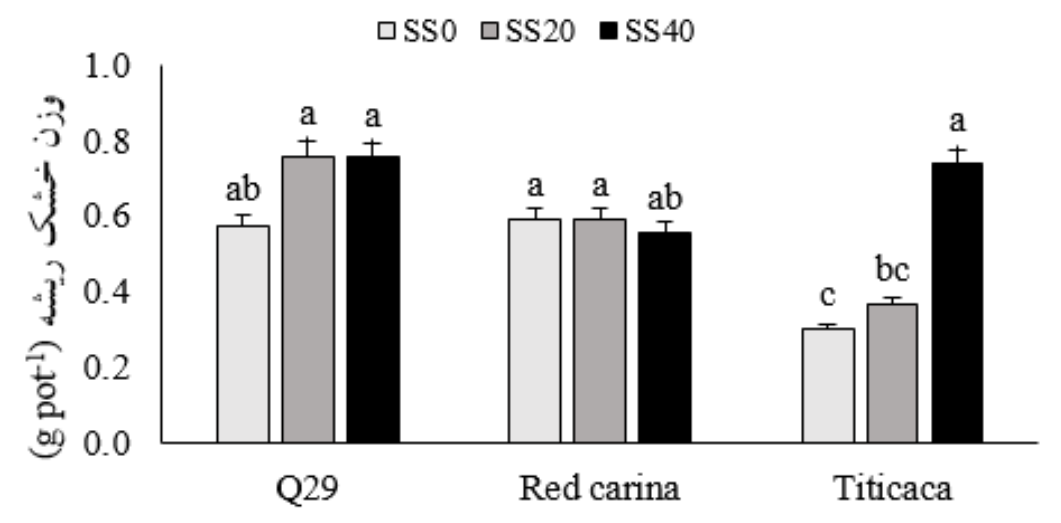

شكل r. تأثير سطوح مختلف لجن فاضلاب (SS) بر وزن خشك ريشه سه زنوتيبٍ كينوا

(ميانگينهاى با حداقل يك حرف مشترك، بيانكر عدم تفاوت معنىدار در سطح ه درصد آزمون دانكن هستند.)

كاربرد لجن فاضلاب در خاك، از طريق افزايش جـذب آب و

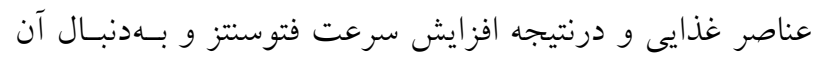

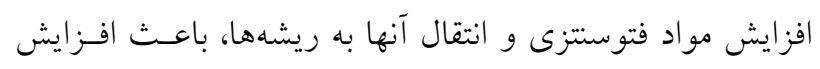

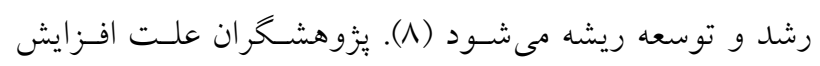

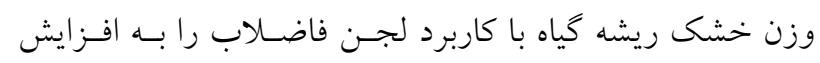

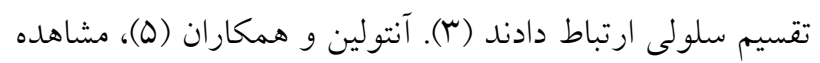

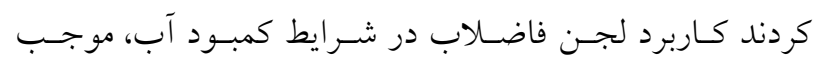

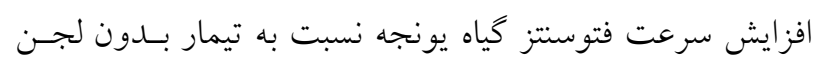

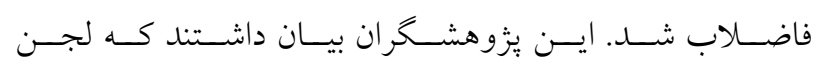

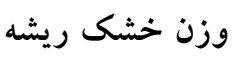

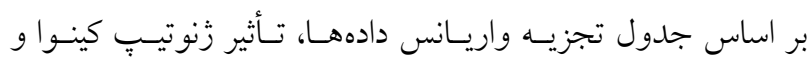
سطوح مختلف لجن فاضلاب در سطح يـك درصــ و اثـر متقابـل آنها در سطح بينج درصد، بر وزن خشك ريشه معنى دار بود (جدول

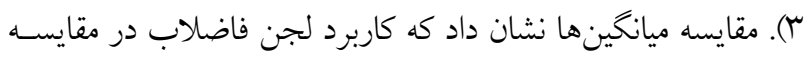

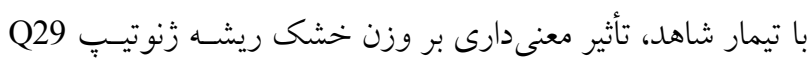

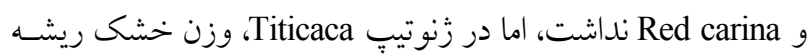

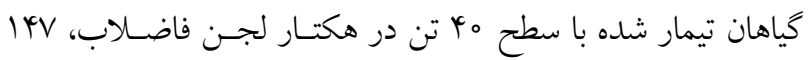
درصد نسبت به تيمار شاهد افزايش يافت (شكل با بان). 


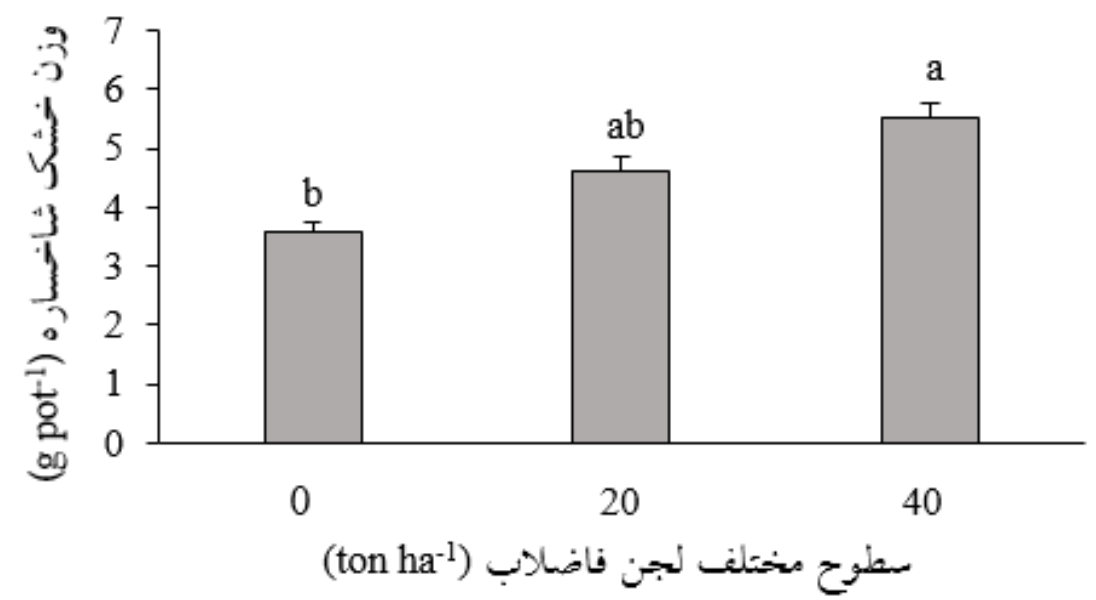

شكل F. تأثير سطوح مختلف لجن فاضلاب بر وزن خشك شاخساره كينوا

(ميانگين هاى با حداقل يك حرف مشترى، بيانكر عدم تفاوت معنى دار در سطح ه درصد آزمون دانكن است.)

فاضلاب با بهبود ويزگى هـاى فيزيكى، شسيميايى و بيولـوزيكى غلظت كلروفيل تأثير نوع زنوتيب كينوا بر غلظت كلروفيل كل در سطح ي-نج خاك به رشد و توسعه ريشه كمك مى كند.

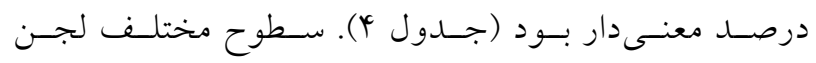

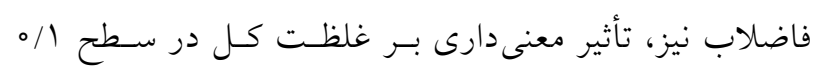

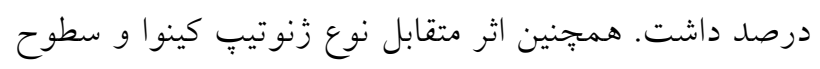
لجن فاضلاب بر غلظت كل در سطح يك درصد معنى دار بود

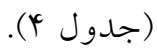

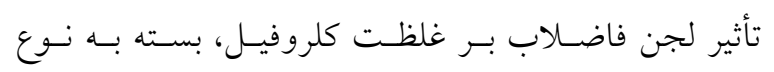

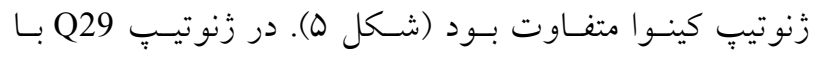

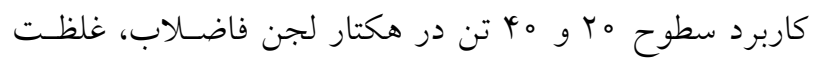

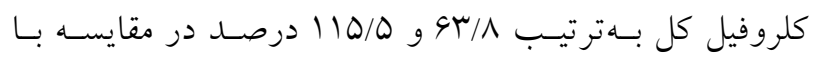

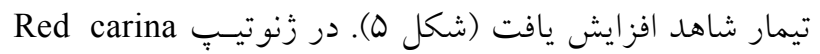

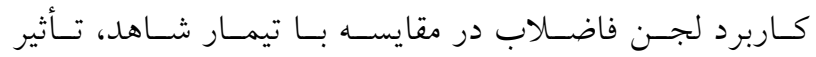

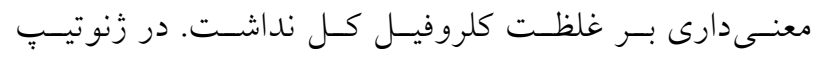

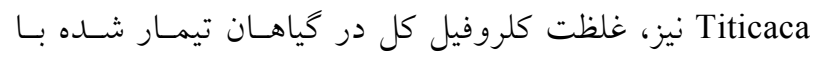

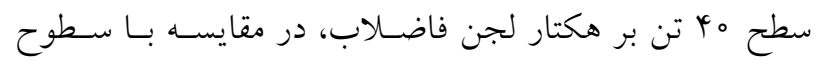

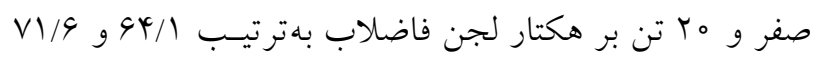

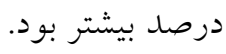

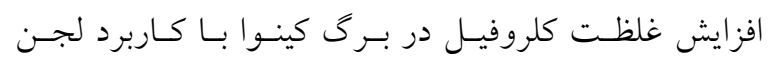

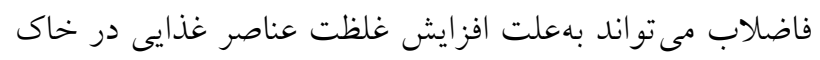
وزن خشك شاخساره

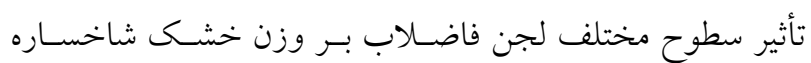

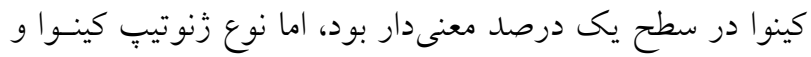

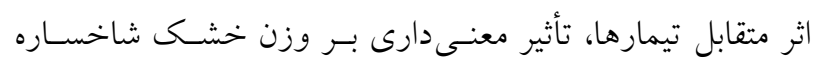

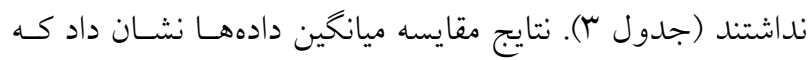

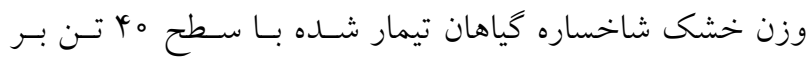
هكتار لجن فاضلاب، ك/ ه درصد بيشتر از تيمار شاهد بود، امـا سطح مY تن بر هكتار لجن فاضلاب در مقايسه با تيمار شـاهد،

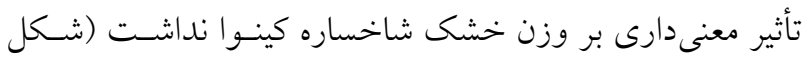

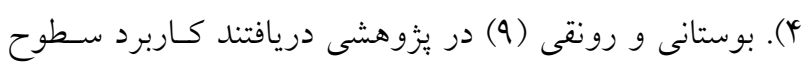

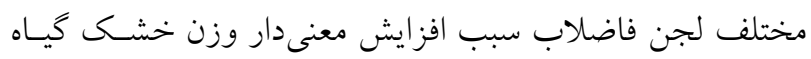
اسفناج شد كه دليل اصلى افزايش عملكـرد اسفناج بـا كـاريبرد

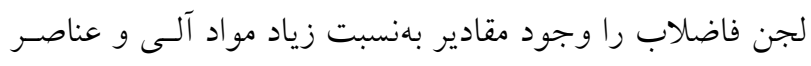

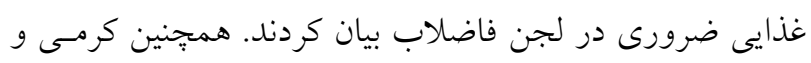

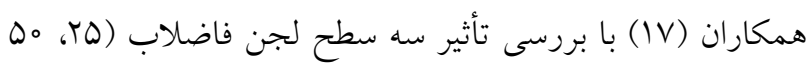

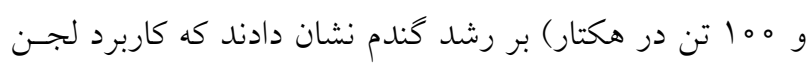

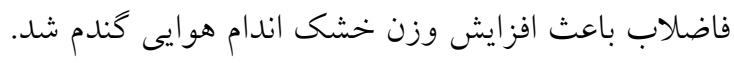


جدول f. نتايج تجزيه واريانس تأثير سطوح مختلف لجن فاضلاب بر غلظت كلروفيل، نيتروزن، فسفر و بتاسيم شاخساره سه زنوتيب كينوا

\begin{tabular}{|c|c|c|c|c|c|}
\hline \multirow[b]{2}{*}{ غلظت يتاسيم } & \multicolumn{2}{|c|}{ ميانخين مربعات } & \multirow[b]{2}{*}{ كلروفيل كل } & \multirow[b]{2}{*}{ درجه آزادى } & \multirow[b]{2}{*}{ منابع تغييرات } \\
\hline & غلظت فسفر & غلظت نيتروزن & & & \\
\hline $1 / / V^{*}$ & $\circ /\left.\circ \varphi\right|^{* * * m}$ & $1 / M$ & $\circ / \circ V^{*}$ & r & رَنوتيبٍ \\
\hline o/vir & 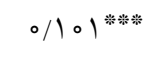 & $19 / 9^{\text {**\%*\% }}$ & 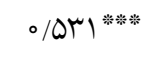 & r & سطح لجن \\
\hline$\circ / \mathrm{V} \wedge$ & $\circ / 04 q^{* * * *}$ & t/AT & $0 / 101^{* * * *}$ & $r$ & زنوتيِ × سطح لجن \\
\hline $0 / r q V$ & $\% \circ \circ \Delta$ & $1 / 94$ &.$/ 011$ & 11 & خطاى آزمايش \\
\hline
\end{tabular}

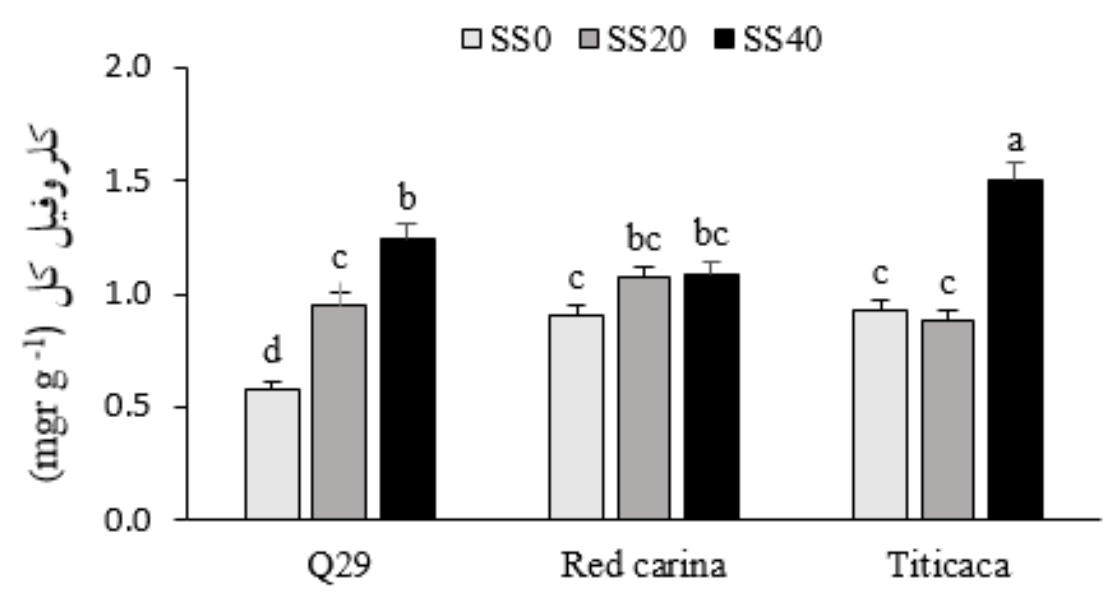

شكل ه. تأثير سطوح مختلف لجن فاضلاب (SS) بر غلظت كلروفيل كل در سه رنوتيب كينوا (ميانكينهاى با حداقل يك حرف مشتر ك، بيانكر عدم تفاوت معنى دار در سطح ه درصد آزمون دانكن است.)

نداشتند (جدول \&). بر اسـاس نتسايج مقايسـه ميـانخين دادههـا،

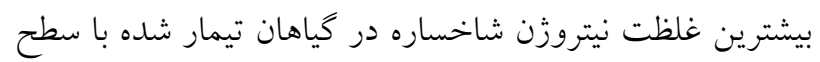

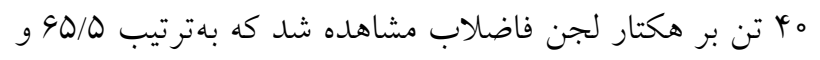

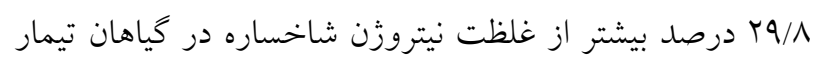

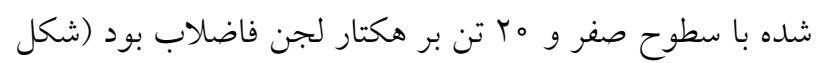

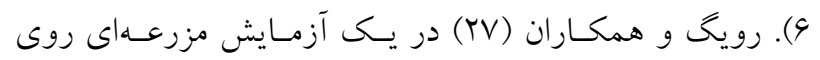

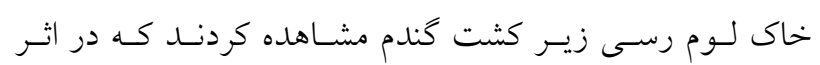

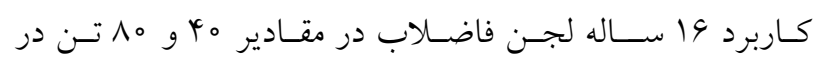

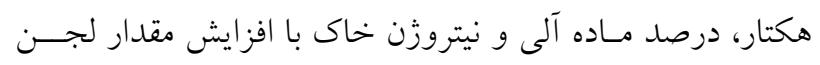

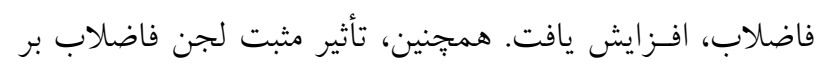

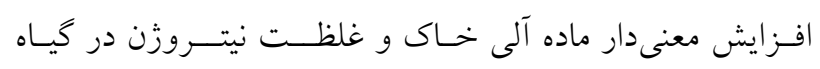
ذرت كــزارش شده است (YN).
بهويزه نيتروزن بر اثر مصرف اين كود باشــ كـه در طـول دوره

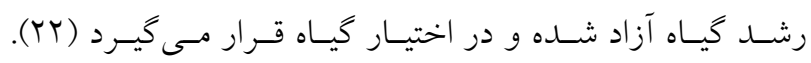

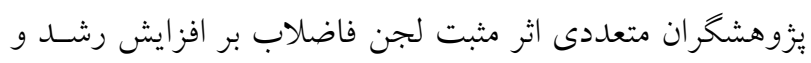

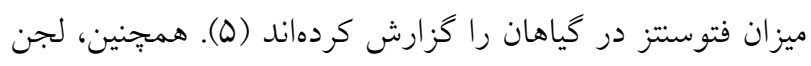

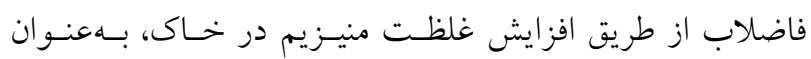

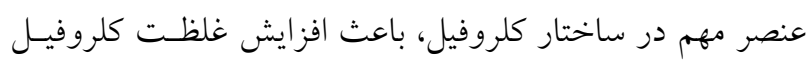
در كَياه مىشود (TQ) (Tه).

غلظت نيتروزن شاخساره تأثير سطوح مختلف لجن فاضلاب بر غلظت نيتروزن شاخساره

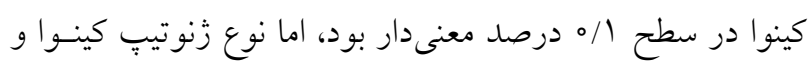
اثر متقابل تيمارها، تأثير معنى دارى بر غلظت نيتروزن شاخسـاره 


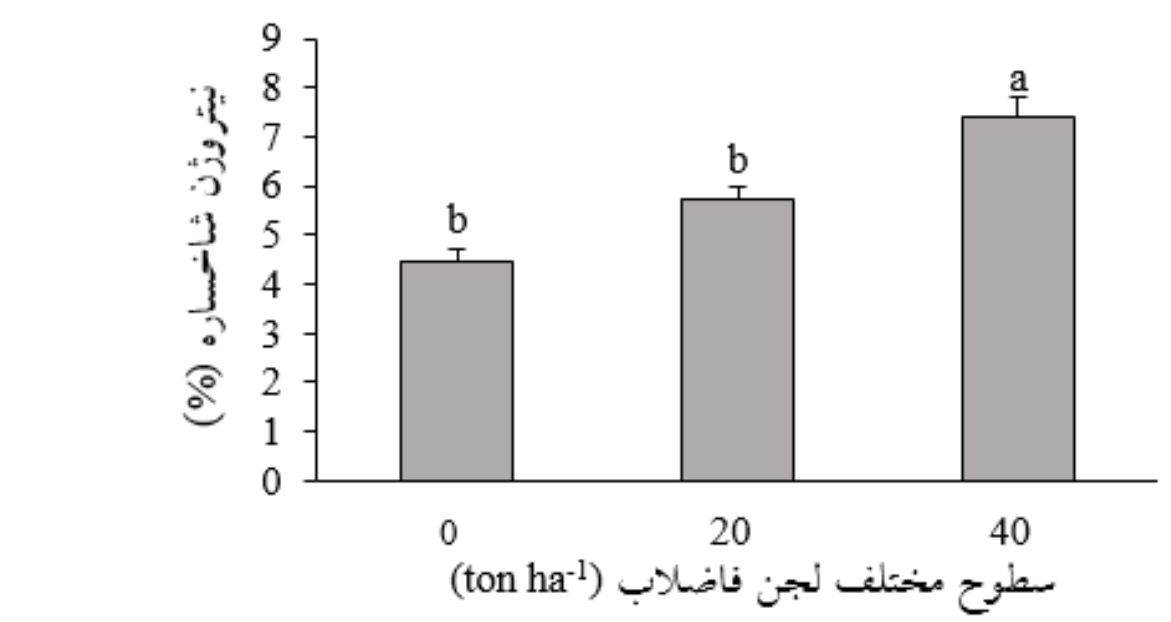

شكل 9. تأثير سطوح مختلف لجن فاضلاب بر غلظت نيتروزن شاخساره

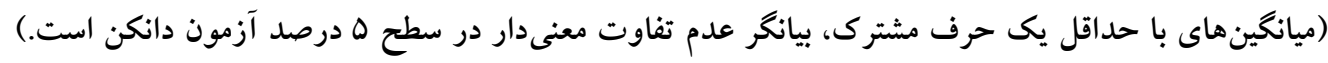

ترتيب جذب آنها بهبود مىيابد (19). يثزوهشكران بيان داشتند

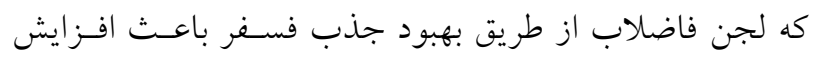

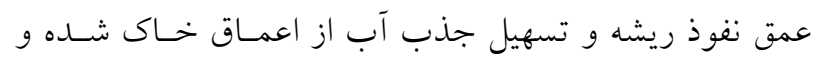

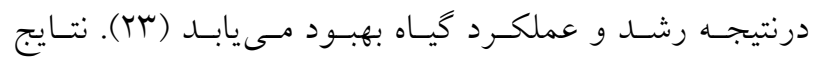

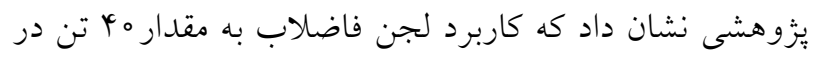

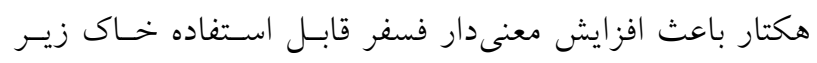

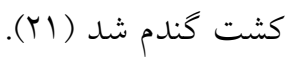

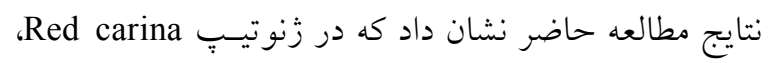

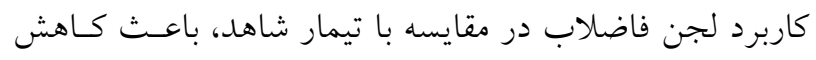
rq/ه درصدى غلظت فسفر شاخساره شد كه اين امر مى تواند

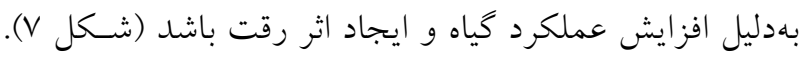

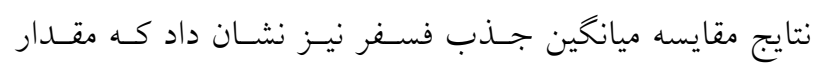

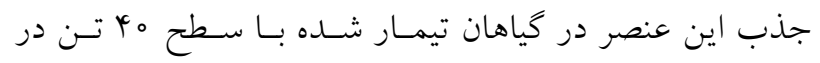
هكتار لجن فاضلاب، بهطور معنى دارى بيشتر از تيمـار شـاهد بود (شكل م).

\section{غلظت يتاسيم شاخساره} بر اساس نتايج تجزيه واريانس دادهها، تأثير نوع زنوتيسبِ كينسوا

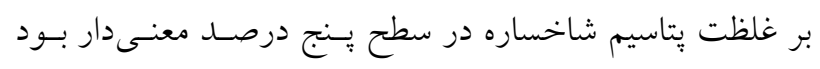

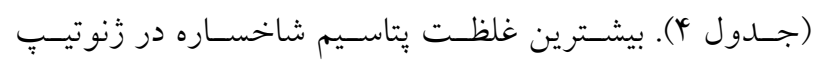

غلظت فسفر شاخساره

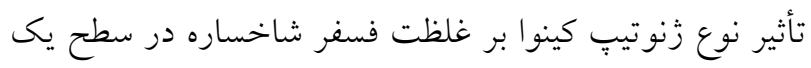

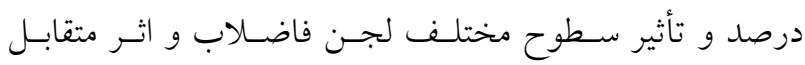

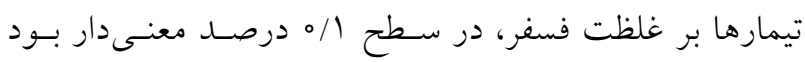

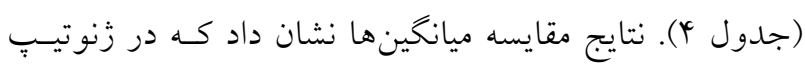
y。 Titicaca, Q29

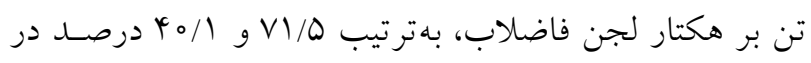

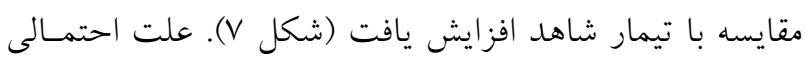

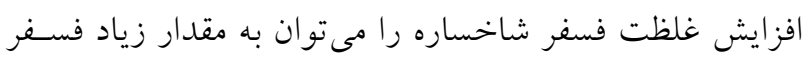

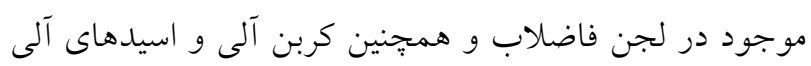

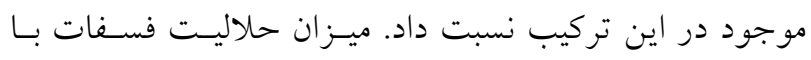

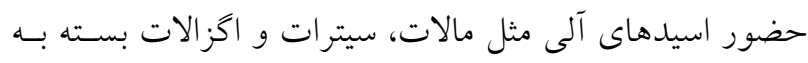

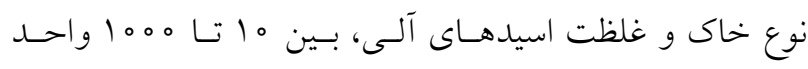

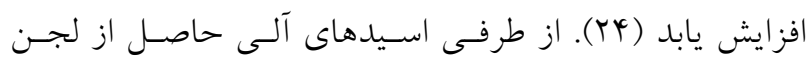

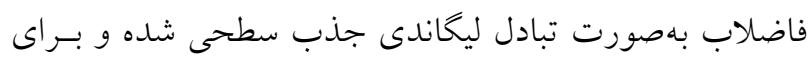

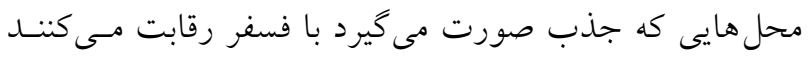
كه درنهايت منجر به افزايش قابليت استفاده فسفات مسى شـودود.

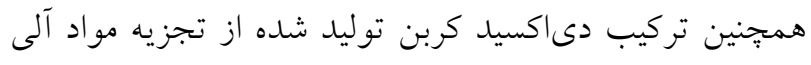

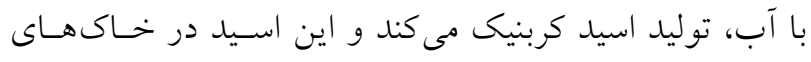

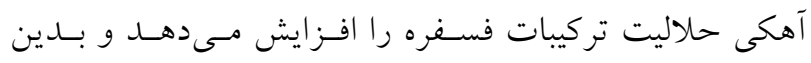




\section{$\square \mathrm{SS} 0 \quad \square \mathrm{SS} 20 \quad \mathrm{SS} 40$}

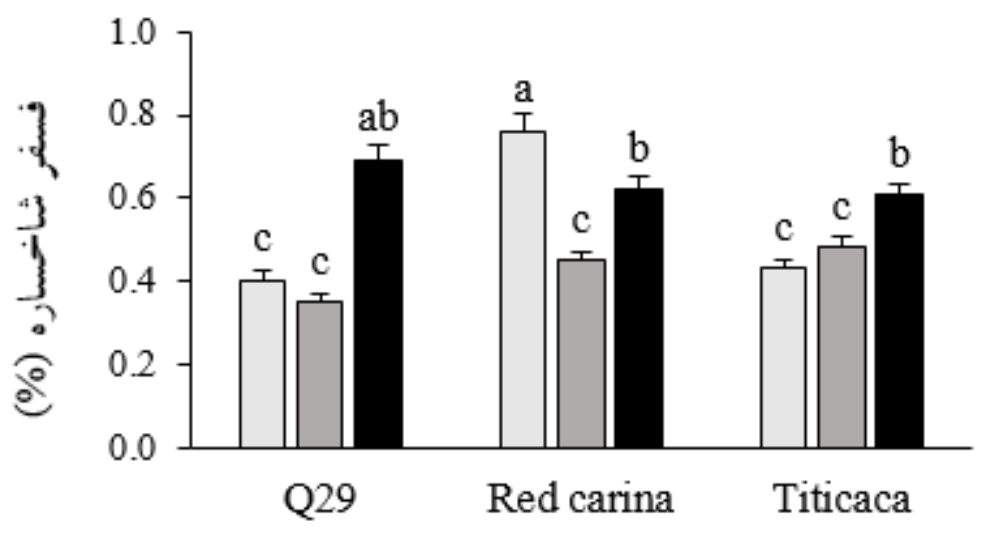

شكل V. تأثير سطوح مختلف لجن فاضلاب (SS) بر غلظت فسفر شاخساره

(ميانگينهاى حداقل يك حرف مشترك، بيانگر عدم تفاوت معنىدار در سطح ه درصد آزمون دانكن است.)

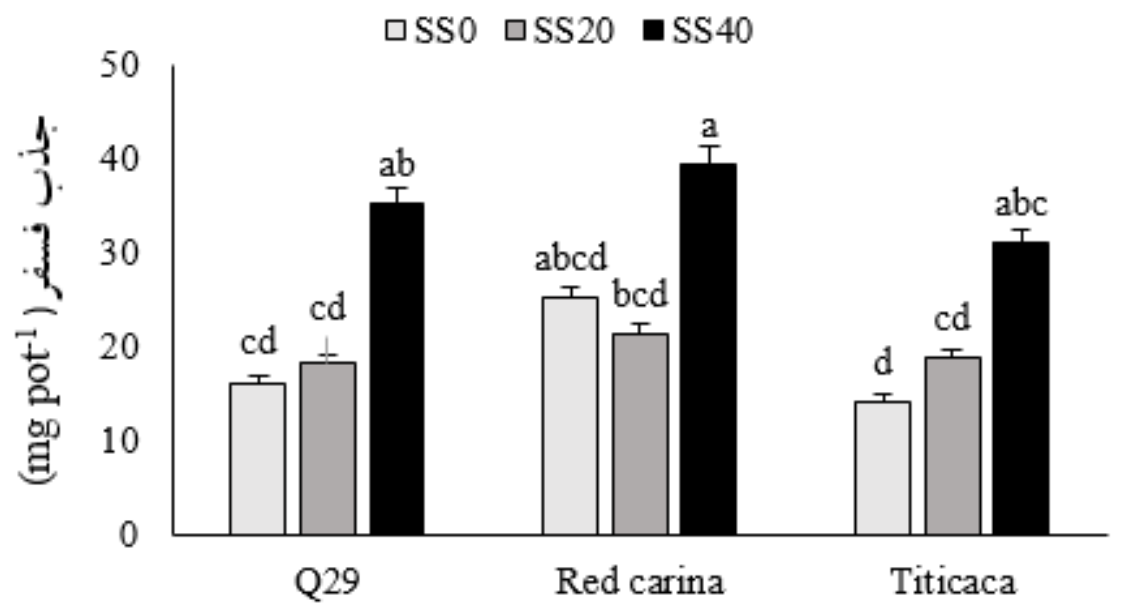

شكل ^. تأثير سطوح مختلف لجن فاضلاب (SS) بر جذب فسفر شاخساره

(ميانگينهاى حداقل يك حرف مشترك، بيانگر عدم تفاوت معنىدار در سطح ه درصد آزمون دانكن است.)

مىشود. البته نتـايج برخـى مطالعـات حــاكى از تـأثير مثبـت لجــن فاضلاب بر غلظت يتاسيم خاك و گياه است كـه بـا نتـايج مطالعـه

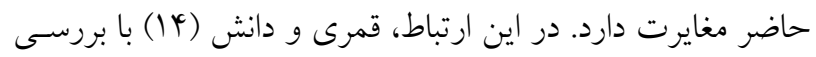
تأثير كـاربرد لجن فاضلاب بر ويزّىىهاى خاك مشاهده كردند كـه

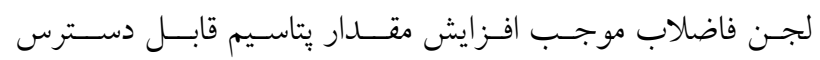
خـاك شد. همجنين نتايج بززوهش رضـانزاد و افيـونى (Y) نشـان داد كاربرد مها تن لجن فاضلاب در هكتار موجب افزايش معنسىار غلظت يتاسيم در ذرت شد.
مشاهده شد كه از اين نظر اختلاف معنى دارى با زنوتيـٍِ Titicaca Red carina سطوح مختلف لجن فاضلاب، تأثير معنى دارى بـر غلظـت يتاسـيم شاخساره كينوا نداشتند (جدول \&). اين نتيجه را مىتوان بـه مقـدار كم يتاسيم لجن فاضـلاب در مقايسـهـ بــا مقـــار نيتـروزن و فسـفر ارتباط داد (جدول (). دليل اصلى اين يديده احتمالاً حلاليت بـالاى

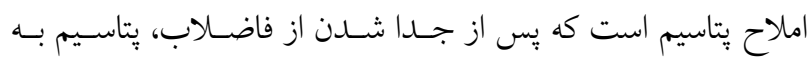
صورت محلول در يُاب باقى مانده و درنتيجه لجن از بتاسيم فقيـر 


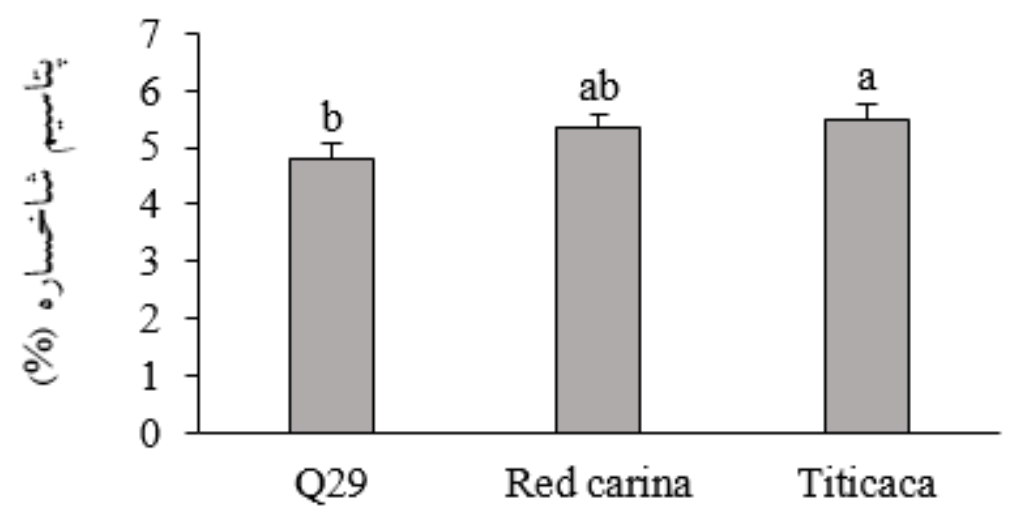

$$
\begin{aligned}
& \text { شكل 9. مقايسه غلظت يتاسيم شاخساره سه زنوتيبٍ كينوا } \\
& \text { (ميانگينهاى با حداقل يك حرف مشترك، بيانگر عدم تفاوت معنىدار در سطح ه درصد آزمون دانكن است.) }
\end{aligned}
$$

$$
\begin{aligned}
& \text { استفاده مكرر از لجن فاضلاب ممكن است سبب تجمع فلـزات } \\
& \text { سنخين در خاك و كياه شود، بنابراين لازم است قبـل از كـاربرد } \\
& \text { لجن فاضلاب، غلظـت فلزات سـنخين موجـود در آن تعيسين و } \\
& \text { مورد ارزيابى قرار گيرد. غلظت عناصر موجود در لجن فاضلاب }
\end{aligned}
$$

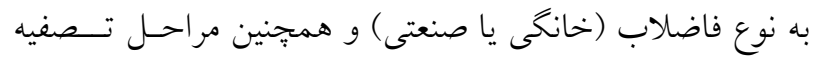

$$
\begin{aligned}
& \text { فاضلاب بستكى دارد. لذا، توصيه مىشود راههاى ورود فلـزات } \\
& \text { سنكين به فاضلاب و لجن فاضلاب بررسى شود تـا بـا كـاهش } \\
& \text { ورود اين فلزات، ارزش كودى لجن فاضلاب افزايش يابد. }
\end{aligned}
$$

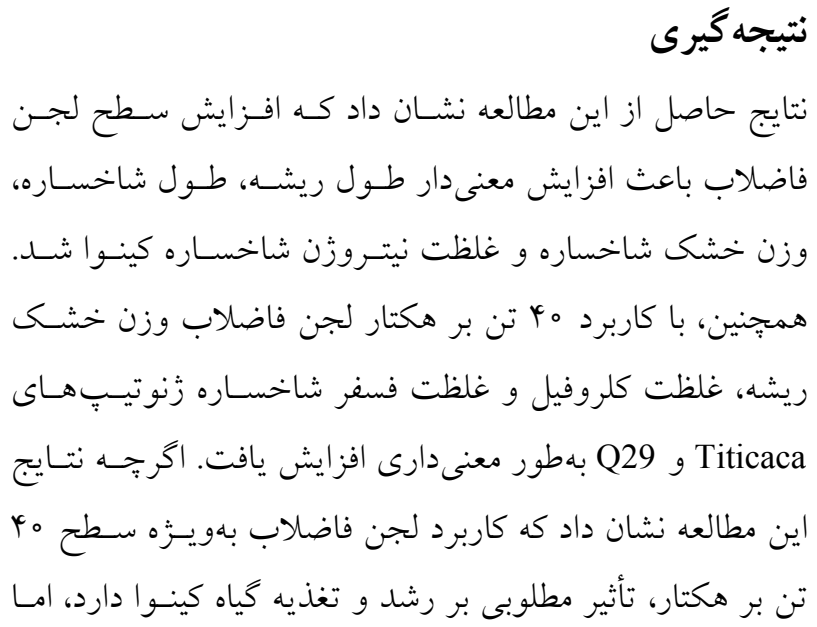

\section{منابع مورد استفاده}

1. Abedi, M. J., S. Nairizi, N. Ebrahimi Birang, M. Maherani, H. Khaledi, N. Mehrdadi and A. M. Cheraghi. 2002. Saline Water Utilization in Sustainable Agriculture. Journal of Iranian National Committee on Irrigation and Drainage 69: 224.

2. Adolf, V. I., S. Shabala, M. N. Andersen, F. Razzaghi and S. E. Jacobsen. 2012. Varietal differences of quinoa's tolerance to saline conditions. Journal of Plant and Soil 357(1-2): 117-129.

3. Amin, A. W., F. K. Sherif, H. El-Atar and H. Ez-Eldin. 2009. Effect of residual and accumulative sewage sludge on heavy metals bioaccumulation: Gene action and some yield parameters of Vicia faba. Research Journal of Environmental Toxicology 3: 60-75.

4. Angin, I. and V. Yaganoglu. 2011. Effects of sewage sludge application on some physical and chemical properties of a soil affected by wind erosion. Journal of Agricultural Science Technology 13: 757-768.

5. Antolin, M. C., I. Muro and M. Sanchez-Diaz. 2010. Application of sewage sludge improves growth, photosynthesis and antioxidant activities of nodulated alfalfa plants under drought conditions. Journal of Environmental and Experimental Botany 68(1): 75-82.

6. Arnon, D. I. 1949. Copper enzymes in isolated chloroplasts: polyphenoloxidase in Beta vulgaris. Journal of Plant Physiology 24: 1-24.

7. Bagheri, M. 2018. Quinoa Cultivation. Seed and Plant Improvement Institue, Tehran, Iran. 
8. Barakah, F. N., S. H. Salem and A. M. Heggo. 1996. Effect of sewage sludge on nodulation and N2 -fixation in alfalfa grown on calcareous loamy soils. Journal of Soil Science and Plant Nutrition 159(3): 289-296.

9. Boostani, H. R. and A. Ronaghi. 2011. Comparison of sewage sludge and chemical fertilizer application on yield and concentration of some nutrients in spinach (Spinosa olerace L.) in three textural classes of a calcareous soil. Journal of Science and Technology of Greenhouse Culture 2(2): 65-74.

10. Chakraborty, U., S. Roy, A. P. Chakraborty, P. Dey and B. Chakraborty. 2011. Plant growth promotion and amelioration of salinity stress in crop plants by a salt-tolerant bacterium. Journal of Recent Research in Science and Technology 3: 61-70.

11. Clapp, C. E., A. J. Palazzo, W. E. Larson, G. C. Marten and D. R. Linden. 1978. Uptake of nutrients by plants irrigated with municipal wastewater effluent. PP. 395-404. In: State of Knowledge in Land Treatment of Wastewater. Army Crops of Engineers, Hanover, N.H.

12. Fathololomi, S., S. H. Asghari and E. Goli Kalanpal. 2015. Effects of municipal sewage sludge on the concentration of macronutrients in soil and plant and some agronomic traits of wheat. Journal of Soil Management and Sustainable 5(2): 49-70.

13. Flowers, T. J. 2004. Improving crop salt tolerance. Journal of Experiment Botany 55(396): 307-319.

14. Ghamari, N. and S. H. Danesh. 2007. Effects of Sewage Sludge Application and Leaching on Soil Chemical Properties, Yield and Quality of Barley. Journal of Agricultural Engineering Research 8(3): 65-80.

15. Jacobsen, S. E., F. Liu and C. R. Jensen. 2009. Does root-sourced ABA play a role for regulation of stomata under drought in quinoa (Chenopodium quinoa Willd.). Journal of Scientia Horticulturae 122(2): 281-287.

16. Jamil, M., M. Qasim, M. Umar and K. Rehman. 2004. Impact of organic wastes (sewage sludge) on the yield of wheat (Triticum aestivum L.) in a calcareous soil. Inter. Journal of Agricultural Biology 3: 465-467.

17. Karami, M., Y. Rezainejad, M. Afyuni and H. Shariatmadari. 2007. Cumulative and residual effects of sewage sludge on lead and cadmium concentration in soil and wheat. Journal of Water and Soil Science 11(1): 79-95.

18. Khanmohammadi, Z., A. H. Khoshgoftarmanesh and A. R. Melali. 2011. Methods of Plant Analysis. Jahad Daneshgahy of IUT. Isfahan.

19. Khorshid, M., A. Hosseinpur and S. Oustan. 2009. Impacts of sewage sludge on phosphorus sorption characteristics and its availability in some calcareous soils. Journal of Water and Soil Science 12(46): 791-802.

20. Kumar, V. and A. K. Chopra. 2016. Agronomical performance of high yielding cultivar of eggplant (Solanum melongena L.) grown in sewage sludge amended soil. Journal of Research in Agriculture 1(1): 1-24.

21. Latare, A. M., O. Kumar, S. K. Singh and A. Gupta. 2014. Direct and residual effect of sewage sludge on yield, heavy metals content and soil fertility under rice-wheat system. Journal of Ecology Engeering 69: 17-24.

22. Mahmoudi, S., N. Najafi and A. Reyhanitabar. 2015. Effect of soil moisture and sewage-sludge compost on some soil chemical properties and alfalfa forage macronutrients concentrations in greenhouse conditions. Journal of Science and Technology of Greenhouse Culture 6(2): 37-55.

23. Malakouti, M. J and M. M. Tehrani. 2005. Role of Microelements on Yield and Quality of Agricultural Productions. Tarbiat Modares Publication, Tehran, Iran.

24. Malakouti, M. J., Z. Khougar and Z. Khademi. 2004. Innovative Approach to Balanced Nutrition of Wheat: A Complication of Papers. Agronomy Department. Ministry of Jihad-e-Agriculture, Sana Publication Compony, Tehran, Iran.

25. Marschner, P. 2012. Marschner Mineral Nutrition of Higher Plants. Third Ed., Elesevier Ltd.

26. Rezaenejad, Y. and M. Afyuni. 2001. Effect of Organic Matter on Soil Chemical Properties and Corn Yield and Elemental Uptake. Journal of Water and Soil Science 4(4) :19-29.

27. Roig, N., J. Sierra, E. Mart, E. Nadal, M. Schuhmacher and J. L. Domingo. 2012. Longterm amendment of Spanish soils with sewage sludge: effects on soil functioning. Journal of Agriculture, Ecosystems and Environment 158: 4148.

28. Saadat. K., M. Barani Motlagh, E. Dordipour and A. Ghasemnezhad. 2012. Influence of sewage sludge on some soil properties, yield and concentration of lead and cadmium in roots and shoots of Maize. Journal of Soil Management and Sustainable 2(2): 27-48.

29. US Environmental Protection Agency (“USEPA 503”). 2002. Federal Water Pollution Control Act (“Clean Water Act"), 33 USC.

30. Yang, A., S. S. Akhtar, S. Iqbal, Z. Qi, G. Alandia and M. S. Saddiq and S. E. Jacobsen. 2018. Saponin seed priming improves salt tolerance in quinoa. Journal of Agronomy and Crop Science 204(1): 31-39. 


\title{
The Effect of Sewage Sudge on the Growth and some Nutrient Elements of Three Quinoa Genotypes in a Calcareous and Saline Soil
}

\author{
F. Afzalinejad ${ }^{1}$, S. Ghasemi ${ }^{1 *}$, S. E. Seyfati ${ }^{2}$ and Sh. Shahbazi ${ }^{1}$
}

(Received: October 28-2019; Accepted: July 05-2020)

\begin{abstract}
Today, the use of organic wastes as fertilizers to improve the physical, chemical and biological properties of soil is common. In this study, to investigate the effect of the sewage sludge on the growth and concentration of chlorophyll, nitrogen, phosphorus and potassium in quinoa plant, a factorial experiment was conducted based on a completely randomized design with three replications in a calcareous soil with electrical conductivity of $13.1 \mathrm{dS} \mathrm{m}^{-1}$. Treatments included three genotypes of quinoa (Red carina, Titicaca, Q29) and three levels of sewage sludge (0, 20 and $\left.40 \mathrm{t} \mathrm{ha}^{-1}\right)$. The results showed that the effects of the quinoa genotype, different levels of sewage sludge and the interaction of treatments on the root dry weight, shoot $\mathrm{P}$ concentration and chlorophyll concentration were significant. Also, the sewage sludge had a significant effect on the shoot length, shoot dry weight and shoot nitrogen concentration. By increasing the level of the sewage sludge, root length, shoot length, shoot dry weight and shoot $\mathrm{N}$ concentration were increased, on average, by $44.7 \%, 48.8 \%, 42.0 \%$ and $46.6 \%$, respectively. Also, application of $40 \mathrm{t}^{-1}$ sewage sludge significantly increased the chlorophyll concentration and shoot P concentration in Q29 and Titicaca genotypes. According to the results of this study, application of sewage sludge can increase the growth of quinoa by improving its nutrition.
\end{abstract}

Keywords: Sewage sludge, Q29, Titicaca, Red carina, Macro nutrients

1. Department of Soil Science, Faculty of Natural Resources, Yazd University, Yazd, Iran.

2. Department of Arid Land and Desert Management, Faculty of Natural Resources, Yazd University, Yazd, Iran.

Corresponding author, Email: s.ghasemi@yazd.ac.ir 